\title{
How many workers are employed in California agriculture?
}

by Philip Martin, Brandon Hooker, Muhammad Akhtar and Marc Stockton

In 2014, the average employment of hired workers in California crop and livestock agriculture, counting all occupations, rose by $10 \%$ to 410,900 . However, although the state reports the number of jobs on farms regularly, it does not report the number of workers who fill these jobs. We analyzed all Social Security numbers reported by farm employers in 2014 and found two workers for each average or year-round equivalent farm job, making the total number of farmworkers employed in agriculture 829,300 , or twice average employment. Approximately $83 \%$ of farmworkers had their maximum earnings with an agricultural employer in 2014, and almost $80 \%$ of those primary farmworkers were employed by crop support firms $(392,000)$ or fruit and nut farms $(154,000)$. Over $60 \%$ of all workers had only one farm employer, followed by $27 \%$ with two or more farm employers, and $35 \%$ were employed in Kern $(116,000)$, Fresno $(96,000)$ and Monterey $(82,000)$ counties. These data show that California has a remarkably stable farm workforce: most farmworkers are attached to one farm employer, often a labor contractor who moves them from farm to farm.

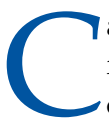
alifornia has led the nation in farm sales since 1950, largely because of the state's specialization in high-value fruit and vegetable crops. California's farm sales of $\$ 54$ billion in 2014 included $\$ 20.8$ billion worth of fruits and nuts, $\$ 8.3$ billion worth of vegetables and melons and $\$ 5.4$ billion worth of horticultural specialties such as greenhouse and nursery products. The value of field crops such as cotton, hay and rice was $\$ 4$ billion, making crop sales of $\$ 38$ billion almost three-fourths of the state's farm sales. Livestock and poultry sales were $\$ 16$ billion, including $\$ 9$ billion (almost $60 \%$ ) from milk. Fruit, vegetable and horticultural (FVH) crops accounted for $90 \%$

Online: https://doi.org/10.3733/ca.2016a0011 Published online August 23, 2016 of the state's crop sales and two-thirds of its farm sales.

The production of many fruits and vegetables is relatively labor intensive, with labor representing $20 \%$ to $40 \%$ of production costs. California growers reported paying $\$ 11.4$ billion in wages in 2014 , making labor costs over $20 \%$ of farm sales. Almost $45 \%$ of these labor costs was for support activities for crop production, primarily payments to farm labor contractors, custom harvesters and other nonfarm businesses that bring workers to farms.
Hired workers, rather than self-employed farm operators and their families, do most of the work on the state's largest farms that produce almost all labor-intensive FVH crops. Most California farmworkers were born in Mexico, and 60\% of crop workers employed on the state's crop farms have been unauthorized for the past decade, according to the National Agricultural Workers Survey, which is 10 percentage points higher than the U.S. average of $50 \%$. Farm employers say that farmworkers present seemingly valid documentation and Social Security numbers (SSNs) when they are hired, so they do not know who is unauthorized.

Several factors, including increased production of labor-intensive crops, a tightening of border controls that has slowed arrivals of new farmworkers, and proposals to give some unauthorized foreigners a temporary legal status, have intensified interest in current and future farmworkers, with farm employers arguing that there are farm labor shortages and worker advocates countering that there is only a shortage of wages to attract and retain farmworkers. While California regularly reports the number of jobs on farms across the state, it does not report 
the number of wage and salary workers who fill them. Our objective was to provide a clearer picture of California's agricultural workforce by determining the actual number of wage and salary workers in agriculture.

\section{Data collection}

The state's Employment Development Department (EDD) obtains data on farmworkers and wages paid when it collects unemployment insurance taxes from employers. Employers who pay more than $\$ 100$ in quarterly wages are required to register with the EDD and pay taxes of up to $6 \%$ on the first $\$ 7,000$ of each worker's earnings to cover the cost of unemployment insurance benefits for laid-off workers. (New employers pay $3.4 \%$ for a period of 2 to 3 years until EDD establishes how many claims their laid-off employees make for unemployment insurance benefits. The maximum charge is $6.2 \%$ of $\$ 7,000$, or $\$ 434$ a year.)

We extracted all wage and salary workers reported by California agricultural employers (North American Industry Classification System, or NAICS 11; census.gov/eos/www/naics/) in 2014 and tabulated all of their farm and nonfarm jobs and earnings in the state; we excluded wage and salary workers in forestry, fishing and hunting. This allowed us to assign workers with more than one job to their primary industry, that is, to the NAICS code of the employer(s) where they had their maximum earnings. We excluded about 800 SSNs because of apparent problems, such as excessive number of jobs reported in a quarter (e.g., more than 10 jobs).

\section{Farm jobs and worker earnings}

Average employment on the state's farms is derived from employer reports of workers on the payroll for the pay period that includes the 12th of the month. Most farmworkers are paid weekly, so an average 410,900 workers employed in 2014 means that this is the average employment of workers on agricultural payrolls during the second week of the month. Workers employed during the month but not during the payroll period that includes the 12th are not included in published average employment data because it is a monthly snapshot, summed and divided by 12 months. Our analysis, however, captures these additional workers because we obtain data on all wage and salary workers hired by agricultural employers at any time, including farmworkers, managers and office workers.

Figure 1 shows average employment in California agriculture since 1990. Average employment rose $10 \%$, reflecting a decline in direct-hire employment on crop farms (NAICS 111), stable employment in animal agriculture (NAICS 112), and a $50 \%$ increase in crop support employment (NAICS 1151), most of which is with farm labor contractors. Since 2010, average

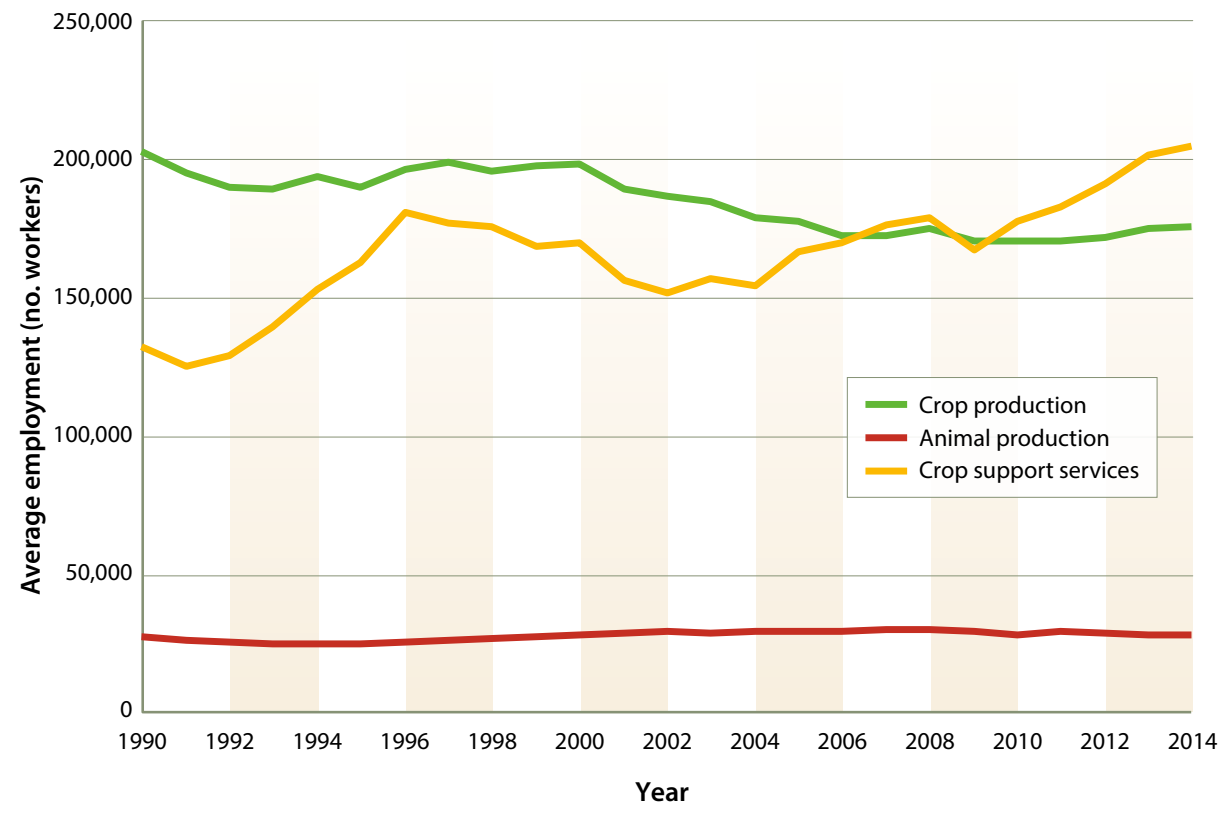

Fig. 1. Average crop, animal and crop support employment in California agriculture, 1990-2014.

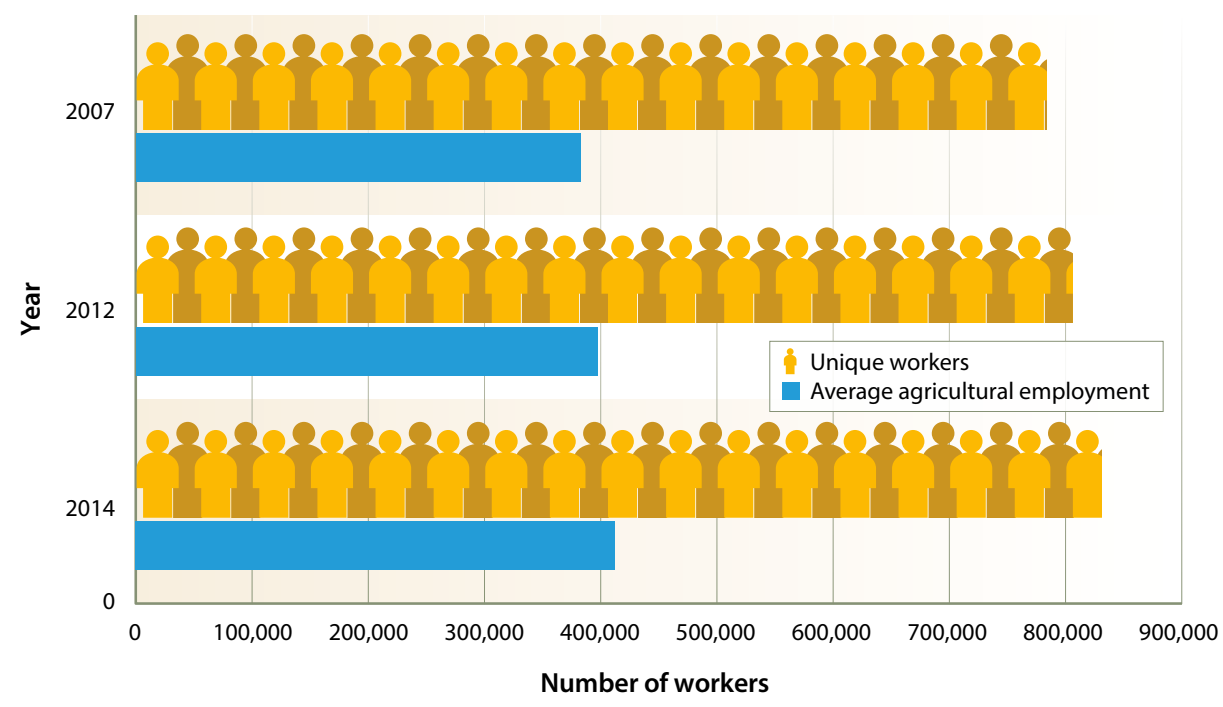

Fig. 2. Average agricultural employment and unique workers, 2007, 2012 and 2014. employment reported by crop support establishments has been rising by 10,000 a year, so that in 2014 nonfarm crop support firms brought more workers to crop farms, an average of over 205,000, than crop farms hired directly, 175,000. In 2014, two-thirds of average employment in crop support services, 207,600, involved farm labor contractors. Very few workers are employed in livestock support services.

Average employment can be considered to be an estimate of full-time equivalent jobs, but it is not the total number of farmworkers. When average employment in California agriculture was 410,900 in 2014, there were 829,000 unique SSNs 
reported by agricultural establishments, a two-to-one worker-to-job ratio (fig. 2). In 2012, when average employment was 395,400 , there were 802,600 unique SSNs, also a two-to-one worker-to-job ratio. There was a similar two-to-one ratio of workers to average jobs in 2007.

The 829,000 people employed in agriculture during 2014 earned $\$ 11.4$ billion from agricultural employers and another $\$ 4.5$ billion from nonfarm employers.

Average earnings for all workers with at least one farm employer were over $\$ 19,000$ in 2014, while average earnings for workers who had their maximum earnings in agriculture were $\$ 16,500$, up almost $8 \%$ from \$15,300 in 2012.

The California jobs of the workers reported by California farm employers can be tabulated, and workers can be assigned to the NAICS or commodity in which they had the highest earnings. For example, approximately 692,000 (83\%) of the 829,000 workers employed in agriculture had their highest earnings from a farm employer in 2014, and 499,000 of these primary farmworkers had only one agricultural employer (table 1).

In 2014, the crop support (NAICS 1151) and fruit and nut (NAICS 1113) sectors had the lowest average earnings, with $\$ 12,719$ for crop support and $\$ 17,600$ for fruits and nuts. This explains why the overall average earnings of primary farmworkers were only $\$ 16,500$ even though all commodities except crop support and fruit and nut had higher average earnings, such as the $\$ 29,223$ average earnings in cattle ranching. agricultural establishments, including (1) 392,000 (57\%) whose maximum earnings were from NAICS 1151 crop support establishments, (2) 154,000 (22\%) whose maximum earnings were from NAICS 1113 fruit and nut establishments and (3) $45,000(6 \%)$ whose maximum earnings

\section{Three sectors - crop support firms, fruit and nut farms, and vegetable and melon farms - accounted for $85 \%$ of all primary farmworkers in 2014.}

Over three-fourths of the $\$ 11.4$ billion in agricultural earnings were from three NAICS codes: 1151 crop support activities ( $\$ 5$ billion), 1113 fruits and nuts (\$2.7 billion) and 1112 vegetables ( $\$ 1.1$ billion). Other major sources of agricultural earnings were NAICS 1114 greenhouses and nurseries (\$884 million) and 1121 cattle and dairy (\$737 million).

\section{Workforce groups}

By assigning all of the state's 829,300 farmworkers to the NAICS code of the employer where they had maximum earnings in 2014, we identified several groups. First, almost 692,000 (83\%) of farmworkers had their maximum earnings from were from NAICS 1112 vegetable establishments. There are over 20 agricultural NAICS codes, but three sectors - crop support firms (often labor contractors), fruit and nut farms, and vegetable and melon farms - accounted for $85 \%$ of all primary farmworkers in 2014.

Second, almost 500,000 farmworkers, or $72 \%$ of primary farmworkers, had only one job in 2014, meaning that three-fourths of workers whose maximum earnings were from agricultural establishments worked for only one agricultural employer in California. These "one-farm employer" workers were in the same three types of establishments as all primary farmworkers: (1) 288,000 (58\%) were in NAICS 1151 crop support

TABLE 1. California farmworkers and earnings, 2014

\begin{tabular}{|c|c|c|c|c|c|c|}
\hline $\begin{array}{l}\text { NAICS } \\
\text { code }\end{array}$ & Category & Primary workers & $\begin{array}{l}\text { Earnings } \\
\text { (\$ millions) }\end{array}$ & Average earnings (\$) & Only job & Share* \\
\hline & All of California agriculture & 691,615 & 11,430 & 16,527 & 499,440 & $72 \%$ \\
\hline 1111 & Oilseed and grain farming & 4,587 & 116 & 25,363 & 3,144 & $69 \%$ \\
\hline 1112 & Vegetable and melon farming & 44,878 & 1,068 & 23,789 & 30,760 & $69 \%$ \\
\hline 1113 & Fruit and tree nut farming & 153,999 & 2,710 & 17,600 & 102,805 & $67 \%$ \\
\hline 1114 & Greenhouse and nursery production & 34,715 & 884 & 25,452 & 26,530 & $76 \%$ \\
\hline 1119 & Other crop farming & 19,052 & 446 & 23,414 & 14,244 & $75 \%$ \\
\hline 1121 & Cattle ranching and farming & 25,224 & 737 & 29,223 & 19,817 & $79 \%$ \\
\hline 1122 & Hog and pig farming & 132 & 4 & 26,804 & 109 & $83 \%$ \\
\hline 1123 & Poultry and egg production & 2,851 & 83 & 29,143 & 2,123 & $74 \%$ \\
\hline 1124 & Sheep and goat farming & 543 & 12 & 21,759 & 465 & $86 \%$ \\
\hline 1125 & Animal aquaculture & 441 & 13 & 30,104 & 324 & $73 \%$ \\
\hline 1129 & Other animal production & 3,069 & 77 & 25,144 & 2,308 & $75 \%$ \\
\hline 1151 & Support activities for crop production & 391,711 & 4,982 & 12,719 & 288,435 & $74 \%$ \\
\hline 1152 & Support activities for animal production & 3,156 & 81 & 25,765 & 2,585 & $82 \%$ \\
\hline \multirow[t]{3}{*}{1153} & Support activities for forestry & 2,589 & 76 & 29,217 & 2,012 & $78 \%$ \\
\hline & Nonfarm & 137,711 & 4,548 & 33,025 & - & - \\
\hline & All workers with at least one agriculture job & 829,326 & 15,978 & 19,266 & - & 一 \\
\hline
\end{tabular}

\footnotetext{
* Percentage of workers whose maximum earnings were in this NAICS and who had only one farm job in 2014.
} 
establishments, (2) 103,000 (21\%) were in NAICS 1113 fruit and nut establishments and (3) 31,000 (6\%) were in NAICS 1112 vegetable establishments.

A closer look at workers whose maximum earnings were in particular NAICS

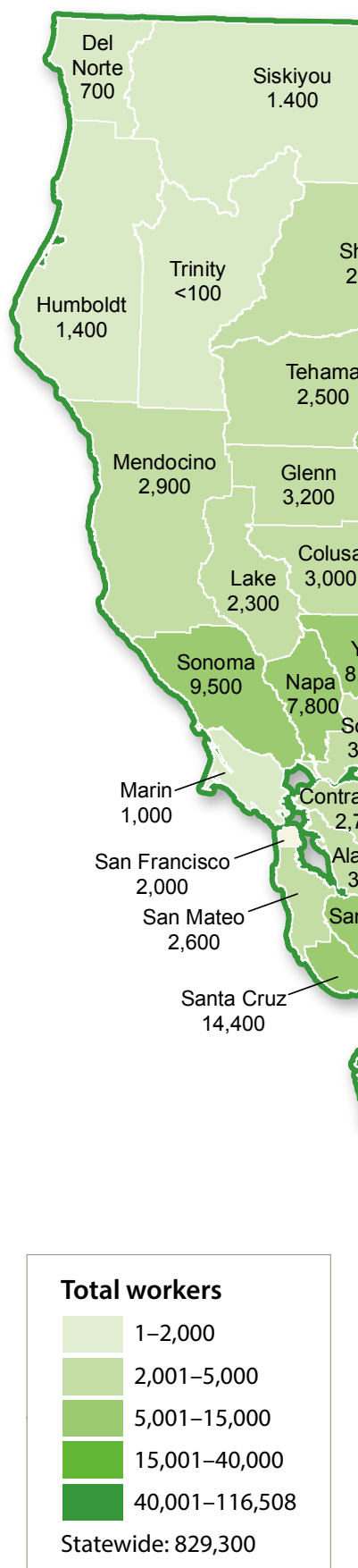

Over 829,000 unique Social Security numbers were reported to the state's Employment Development Department by California agricultural employers in 2014. When workers were assigned to the county in which they had their primary (or highest-earning) job, the following three counties had $35 \%$ of the state's farmworkers: Kern $(116,000)$, Fresno $(96,000)$ and Monterey $(82,000)$. Source: Quarterly Census of Employment and Wages, CA EDD Base Wage File.

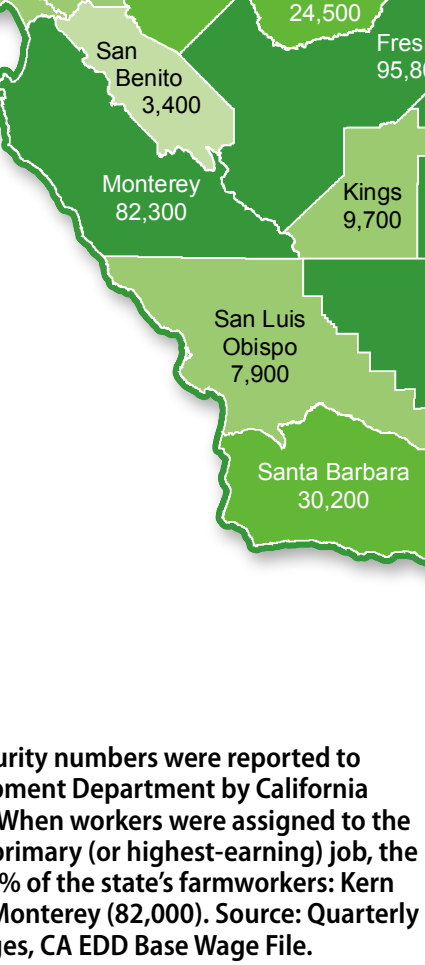

codes found that 103,000 , or two-thirds of the 154,000 directly hired fruit and nut workers, were employed by just one fruit and nut establishment. Similarly, over 288,000, or almost three-fourths of the 392,000 workers whose maximum

earnings were in crop support, had only one crop-support employer, although crop support employees may work on multiple farms during the year. Over three-fourths of workers in livestock production were employed by one livestock establishment.

Third, there were 94,000 primary farmworkers with at least two farm employers in 2014. Of these, half had their maximum earnings from NAICS 1151 crop support establishments (table 2), but only an eighth of crop support workers had two farm employers. About $20 \%$ of those whose maximum earnings were from fruit (1113) and vegetable (1112) growers had at least two farm employers.

Almost 72,000 farmworkers had at least one farm and at least one nonfarm employer in 2014, and almost $60 \%$ of these workers had their maximum earnings from NAICS 1151 crop support establishments, followed by $18 \%$ whose maximum earnings were from fruit growers. The most common nonfarm jobs were in manufacturing; professional, scientific and technical services; and accommodation and food services.

Finally, some 26,000 workers whose maximum earnings were in agriculture had at least two farm employers and at least one nonfarm employer. Over half of these workers had their maximum earnings in crop support services and over a quarter in fruit and tree nut farming (table 2).

The combined 220,500 workers with at least two employers in 2014 were most often employed in the same county. For example, over $8 \%$ of these twoemployer workers had two jobs in Kern County, followed by $6 \%$ with two jobs in Fresno County and 5\% with two jobs in Monterey County.

Approximately $22 \%$ of workers with two jobs in 2014 were employed in 1113 fruits and nuts and 1151 crop support, followed by $5 \%$ to $6 \%$ who combined 1151 with
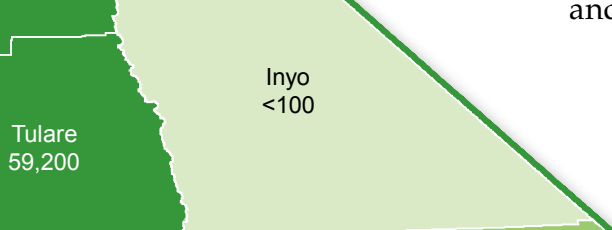

59,200

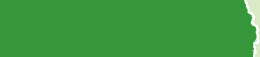




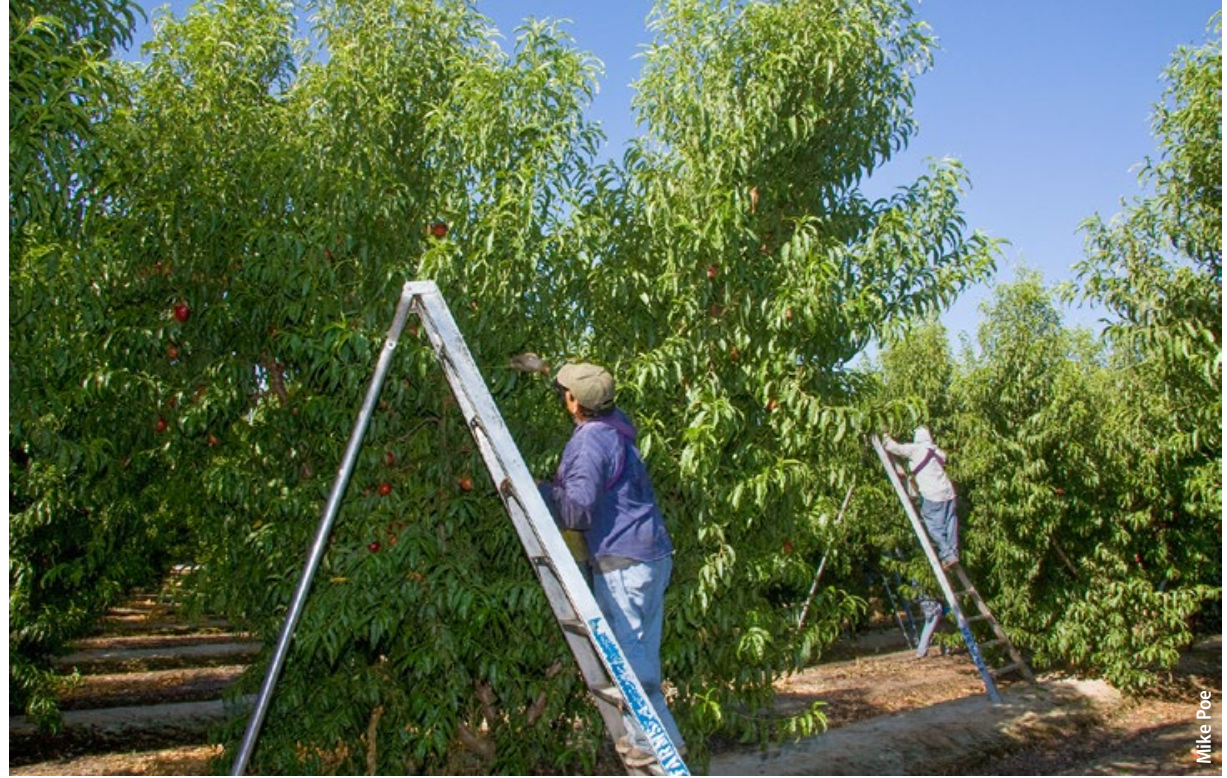

In 2014 , the average earnings for workers in the fruit and tree nut farming sector were $\$ 17,600$.

5613 employment services, 1113 fruits and nuts with another 1113 job, at least two 1151 crop support jobs, and 1112 vegetables with 1151 crop support.

\section{Implications}

The number of wage and salary workers employed on California farms is of great interest because of fears that farm labor shortages could reduce the state's production of labor-intensive crops. Knowing how many wage and salary workers are employed sometime during the year gives a more accurate portrait of worker earnings and mobility. In 2014, agricultural employers hired over 829,000 unique workers, which suggests that two workers filled the average year-round equivalent job, meaning that the total farm workforce was twice average farm employment.

Although the unemployment insurance data do not include the characteristics of farmworkers, they do show that most farmworkers have only one farm employer during the year, which indicates that California has a very stable agricultural workforce. An earlier study reported almost three workers for each year-round farm job in the 1990s, and a higher share of workers with more than one farm job (Khan et al. 2004). Analysis of data for
2007 and 2012 finds that the ratio had dropped to two unique workers for each average agricultural job (Hooker et al. 2015). The 2014 analysis presented here shows that this two-to-one worker-to-job ratio has remained constant. CA

P. Martin is Professor Emeritus of Agricultural and Resource Economics at UC Davis, M. Akhtar is Deputy Division Chief of the Labor Market Information Division in the California Employment Development Department (EDD), and B. Hooker and M. Stockton are Research Program Specialists at EDD. The views expressed in this report do not necessarily reflect the policies of the Employment Development Department or the State of California.

\section{References}

Hooker B, Martin P, Wong A. 2015. California Farm Labor. Jobs and Workers. ARE Update. Vol 18. No. 6 JulyAugust. http://giannini.ucop.edu/are-update/18/6/

california-farm-labor-job/.

Khan A, Martin P, Hardiman P. 2004. Expanded production of labor-intensive crops increases agricultural employment. Calif Agr 58(1):35-9. http://calag. ucanr.edu/Archive/?article=ca.v058n01p35.

TABLE 2. Workers with two farm jobs and nonfarm jobs, 2014

\begin{tabular}{|c|c|c|c|c|c|}
\hline $\begin{array}{l}\text { NAICS } \\
\text { code }\end{array}$ & Category & $\begin{array}{l}\text { At least } 2 \text { agricultural } \\
\text { employers }\end{array}$ & Share* & $\begin{array}{l}\text { At least } 1 \text { agricultural and } \\
1 \text { nonagricultural employer }\end{array}$ & $\begin{array}{l}\text { At least } 2 \text { agricultural employers and } \\
1 \text { or more nonagricultural employer }\end{array}$ \\
\hline & Primary agricultural workers & 94,127 & $100 \%$ & 71,758 & 26,290 \\
\hline 1111 & Oilseed and grain farming & 722 & $1 \%$ & 515 & 206 \\
\hline 1112 & Vegetable and melon farming & 7,690 & $8 \%$ & 4,277 & 2,151 \\
\hline 1113 & Fruit and tree nut farming & 30,291 & $32 \%$ & 13,420 & 7,483 \\
\hline 1114 & Greenhouse and nursery production & 2,567 & $3 \%$ & 4,710 & 908 \\
\hline 1119 & Other crop farming & 2,600 & $3 \%$ & 1,643 & 565 \\
\hline 1121 & Cattle ranching and farming & 1,869 & $2 \%$ & 2,920 & 618 \\
\hline 1122 & Hog and pig farming & 5 & $0 \%$ & 15 & 3 \\
\hline 1123 & Poultry and egg production & 161 & $0 \%$ & 492 & 75 \\
\hline 1124 & Sheep and goat farming & 15 & $0 \%$ & 54 & 9 \\
\hline 1125 & Animal aquaculture & 16 & $0 \%$ & 91 & 10 \\
\hline 1129 & Other animal production & 231 & $0 \%$ & 439 & 91 \\
\hline 1151 & Support activities for crop production & 47,555 & $51 \%$ & 41,689 & 14,032 \\
\hline 1152 & Support activities for animal production & 75 & $0 \%$ & 471 & 25 \\
\hline 1153 & Support activities for forestry & 77 & $0 \%$ & 464 & 36 \\
\hline
\end{tabular}

\footnotetext{
* Percentage of workers whose maximum earnings were in this NAICS and who had at least 2 agricultural employers in 2014.
} 